\title{
Influence of Different Pulse Length towards Motility and Viability of Ornamental Japanese Carp (Cyprinus carpio Var. Koi) Sperm through Electroporation Method
}

\author{
Diana Aisyah ${ }^{1 *}$, Agoes Soeprijanto², Yuni Kilawati² $^{2}$ \\ ${ }^{1}$ Master Program of Aquculture, Faculty of Fisheries and Marine Sciences, University of Brawijaya, Malang, Indonesia \\ ${ }^{2}$ Faculty of Fisheries and Marine Sciences, University of Brawijaya, Malang, Indonesia
}

\begin{abstract}
Successful studies about implementation of electroporation method which sperm becomes gene transfer medium for fish transgenesis have reported. Motility and viability are two major factors in successful of electroporation. The objective of the study was to determine optimal pulse length of electroporation towards the motility and viability of Koi fish sperm. The study was conducted at the Central Laboratory of Biological Sciences and Reproduction of Brawijaya University. The data analysis was conducted using completely randomized design. The electroporation method was carried out using voltage of 30 volt with pulse number of 4 times. The pulse length of the electroporation (based on treatment) was $0.5,1$ and $1.5 \mathrm{~ms}$. The result showed the highest percentage of motility was $3.67 \%$ in treatment A (pulse length $0.5 \mathrm{~ms}$ ) with coefficient correlation $R^{2}=0.9643$ and the best percentage of viability was $79.67 \%$ in treatment $A$ (pulse length $0.5 \mathrm{~ms}$ ) with coefficient correlation $\mathrm{R}^{2}=1$. Correlation between the pulse length treatment (electroporation) toward motility and viability of Koi fish sperm, in which longer duration of pulse length treatment (electroporation) would decrease the motility and viability percentage of the fish sperm.
\end{abstract}

Keywords: Electroporation, Motility, Pulse length, Sperm, Viability.

\section{INTRODUCTION}

Electroporation is one of the effective and efficient gen transfer method widely applied in aquaculture besides microinjection. The principle of electroporation is to form reparable-holes on cell membrane with help of electrical current and the cells are suspended in DNA solution which will then enter the cell through the already formed hole [1].

Electroporation method is mostly conducted using sperm as vector that carries a foreign gene to be introduced (sperm-mediated gene transfer). Based on some previous studies, it has been found that sperm has unique ability as natural vector for carrying foreign gene [2]. The sperm electroporation method is simpler and massive, in which large quantities of sperm can be inserted in transgenes [3].

The success of gene transfer method by electroporation method using sperm as the gene transfer media depends on the voltage level and the concentration of DNA vector during electroporation [4]. The integration of DNA into the sperm depends on the electric voltage $\left(\mathrm{Vcm}^{-1}\right)$, pulse number and concentration of DNA,

\footnotetext{
* Correspondence author:

Diana Aisyah

Email : dianaaisyah3@gmail.com

Address : Faculty of Fisheries and Marine Sciences, University of Brawijaya, Jl. Veteran Malang, 65145
}

where as the transfer efficiency of DNA with sperm-media electroporation is strongly affected by electric voltage and pulse length [5].

The main factor of success in fish sperm transgenesis is to succeed in maintaining the quality of sperm which includes motility and viability for fertilization. Previous research has shown that Chinook Salmon (Oncorhynchus tshawytscha) sperm activity decreased from $82 \%$ to $2 \%$ post electroporation [5], it is important to find out how to use electroporation method optimally. The study of optimum pulse length in Ornamental Japanese carp (Cyprinus carpio Var. Koi) fish transgenesis using electroporation method has not been studied and therefore it is necessary to conduct experiment on influence of different pulse length towards motility and viability of Ornamental Japanese carp fish sperm to get optimum result. The purpose of this research is to describe the influence of electroporation method using voltage level (30 volt) and different pulse length towards motility and viability of Ornamental Japanese carp fish (Cyprinus carpio Var.Koi) sperm.

\section{MATERIALS AND METHODS}

This experiment was conducted in May 2017 at Fish Breeding and Reproduction Laboratory, Faculty of Fisheries and Marine Science and Central Laboratory of Life Sciences of Brawijaya 
University, Malang. The materials used in this research were Ornamental Japanese carp fish sperm, physiological solution, eosin negrosin, tissue, aluminum foil, and aquades. The equipments were a set of BIO-RAD Gene Pulser Xcell $^{\mathrm{TM}}$ including electrophorator, shock pod and cuvet, inverted Olympus BX 51 microscope, binoculars Olympus CX 21 microscope, micropipet, appendorf, blue tip, yellow tip, white type, digital camera, glass object, petri disk, and handtally counter.

The experimental design used in this study was Completely Randomized Design. There were 3 treatments and 1 control; each was repeated 3 times. The treatments were as follow:

Treatment $A=$ Pulse Length for $0.5 \mathrm{~ms}$.

Treatment $B=$ Pulse Length for $1.0 \mathrm{~ms}$.

Treatment $C=$ Pulse Length for $1.5 \mathrm{~ms}$.

Treatment $\mathrm{K}=$ No treatment

\section{Collection of Sperm}

Fish sperm was obtained from male fish of which gonad had been mature by stripping. The sperm resulting from the stripping was inserted into $1 \mathrm{~mL}$ syringe and Na-physiologically was added as a diluent with a ratio of $1: 1$ and then, these were put into the appendorf [6].

\section{Electroporation Process}

1 set of Gene Pulser Xcell ${ }^{\mathrm{TM}}$ Electroporation System Biorad was used during electroporation process. $25 \mu \mathrm{L}$ of sperm was inserted into the electrophorator cuvet $(0.2 \mathrm{~mm})$ [7]. Next, it was pulsed with 30 volt electric level [8], pulse length was according to treatment and the pulse number was 4 times. Post electroporation, 275 physiological $\mathrm{NaCL}$ (total of $300 \mu \mathrm{L}$ solution) was added into the sperm [9]. The following step was to observe the motility and viability of the post electroporation sperm.

\section{DATA COLLECTION Sperm Viability}

Staining was the method used for observing sperm viability or survival of the sperm. $5 \mu \mathrm{L}$ sperm was taken and $1 \mu \mathrm{L}$ was dripped on the object glass. The next step was to add eosin negrosin dye and polish it with cover glass. The following step is to wait until it was dry and observe it under the microscope. Having finished, the researchers calculated the percentage of living sperm of which color was clear and dead sperm of which color was reddish using handtally counter. Susilowati [10]'s formula was adapted for calculation of the sperm viability:

$$
\text { Viability }=\frac{\Sigma \text { Living Sperm }}{\Sigma \text { Dead Sperm }} \times 100 \%
$$

\section{Sperm Motility}

To observe sperm motility, the researchers took $1 \mu \mathrm{L}$ of the post electroporation sperm and put it on the glass object. Then added water, and covered it with cover glass and observed sperm motility under the inverted microscope for $7 \mathrm{sec}$ onds. Sperm percentage was observed using the scoring criterion adapted from Dewi [11]. Table 1 described the scoring criteria.

\begin{tabular}{clc}
\multicolumn{3}{c}{ Table 1. Motility Scoring } \\
\hline Percentage & \multicolumn{1}{c}{ Criteria } & Score \\
\hline$>70 \%$ & $\begin{array}{l}\text { Spermtozoa moved forward } \\
\text { and rapidly with various tail } \\
\text { movement }\end{array}$ & 5.0 \\
& $\begin{array}{l}\text { Spermtozoa moved forward } \\
\text { and showed rapid movement }\end{array}$ & 4.0 \\
& $\begin{array}{l}\text { Spermtozoa moved forward } \\
\text { and some of them showed }\end{array}$ & 3.0 \\
& $\begin{array}{l}\text { rapid movement } \\
\text { Spermtozoa moved forward }\end{array}$ & 2.0 \\
$10-55 \%$ & $\begin{array}{l}\text { Spermtozoa was moving } \\
\text { Most of the spermtozoa did }\end{array}$ & 0.5 \\
& $\begin{array}{l}\text { not move } \\
\text { No movement }\end{array}$ & 0.0 \\
\hline
\end{tabular}

\section{Data Analysis}

The data analysis method was variance analysis (ANOVA) to match the design of the study, Completely Randomized Design. When there was significant difference, the researchers continued the experiment using Least Significance Different (LSD) test. Regression analysis was used to describe the correlation between the treatment and the result used; the objective of regression analysis is to determine the nature of the regression function which gives information about the effect of the best treatment towards the response.

\section{RESULT AND DISCUSSION \\ Motility of the Post Electroporation Sperm}

Based on the result, each of the treatments after electroporation method with different influence of pulse length towards motility percentage of the Ornamental Japanes Carp fish sperm; the percentage was compared to the control (no treatment). Table 2 described percentage of the sperm motility.

The table 2 showed that treatment A (pulse length for $0.5 \mathrm{~ms}$ ) resulted in the highest motility percentage $(3.67 \%)$ whereas treatment C (pulse 
length for $1.5 \mathrm{~ms}$ ) resulted in the lowest percentage of motility $(0.67 \%)$.

Table 2. Sperm Motility (\%)

\begin{tabular}{cccccc}
\multicolumn{7}{c}{ Table 2. Sperm Motility (\%) } \\
\cline { 2 - 4 } Treatment & \multicolumn{7}{c}{ Repetetion } & \multirow{2}{*}{ Total } & Average \\
\cline { 2 - 5 } & $\mathbf{1}$ & $\mathbf{2}$ & $\mathbf{3}$ & & \\
\hline A & 4 & 3 & 4 & 11 & 3.67 \\
B & 2 & 3 & 3 & 8 & 2.67 \\
C & 0.5 & 1 & 0.5 & 2 & 0.67 \\
\hline Total & & & & 21 & \\
\hline Control & 5 & 4 & 5 & 14 & 4.6 \\
\hline
\end{tabular}

The motility showed the decreasing sperm motility during each of the treatments. The control (no treatment) had the highest percentage of sperm sperm motility (4.6\%) compared to the treatment where the pulse length was applied. It showed the higher pulse length caused decrease in the percentage of post electroporation sperm motility. According to Tsong [12], the pulse length (milliseconds) and electrical voltage level (volts) may cause change in pore size of the sperm cell membranes and will be decreasing quality of the sperm.

Based on the result of the variance analysis in Table 3, the shock duration of the treatment had significant influence towards the motility of the Ornamental Japanese Carp fish sperm after electroporation treatment. It was indicated by the comparison between F-ratio, F-table $5 \%$ and Ftable $1 \%$.

\begin{tabular}{lcccccc}
\multicolumn{7}{c}{ Table 3. Variance Analysis } \\
\hline $\begin{array}{l}\text { Source of } \\
\text { Variance }\end{array}$ & Df & SS & MS & F & F 5\% & F 1\% \\
\hline Treatment & 2 & 14 & 7 & & & \\
Random & 6 & 1.5 & 0.25 & 28 & 5.14 & 10.92 \\
Total & 8 & & & & & \\
\hline
\end{tabular}

The polynomial testing (Fig. 1) resulted in the following linear equation, $Y=-1.5 x+5.3333$ where correlation coefficient between the pulse length and the sperm motility of $\mathbf{R}^{2}=\mathbf{0 . 9 6 4 3}$. In other words, there was very significant correlation between the pulse length during the electroporation method and the motility of Ornamental Japanes carp fish sperm.

The analysis showed that the longer of pulse length causes more decreasing percentage of sperm motility. The highest motility was the result of treatment $A(0.5 \mathrm{~ms})$ in which the percentage was $3.67 \%$. It is important to describe the quality of the fish sperm because it will determine the success of the fertilization process using egg as the medium. If the quality of sperm decreased, it would affect the work of sperm. Percentages of sperm motility should not be lower than $50 \%$ [13].

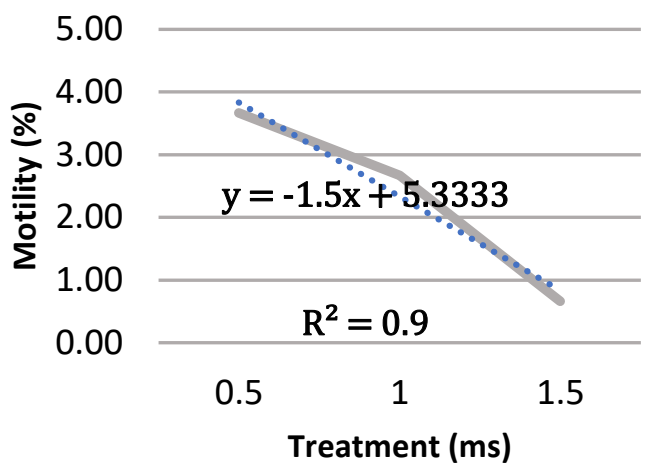

Figure 1. Correlation between Different pulse length and Sperm Motility Chart

Motility of fish sperm representing the sperm survival would decrease with increasing voltage level and pulse length [14]. The shape of sperm plasma membrane was related to the motility and viability of spermtozoa. If the plasma membrane was damaged, the enzymes that played a role in energy metabolism would be lessen or even be lost. This may lead to a decrease in energy sources so that sperm movement will slow down, and would certainly decrease the life and power of fertilization [15].

\section{Viability of Post Electroporation Sperm}

Table 4 described the average viability of the treatment that analyzed the influence of different pulse length during the electroporation towards Ornamental Japanes carp fish sperm. Based on Table 4, treatment A (0.5 ms) resulted in the highest percentage of viability $(79.67 \%)$ while treatment $C(1.5 \mathrm{~ms})$ resulted the lowest percentage of viability $(63.00 \%)$. The viability of the control (no treatment) was $90.66 \%$ or higher than that of the treatments. Increasing of pulse length lead to decreasing percentage of sperm viability. Furthermore, each treatment had different viability result.

\begin{tabular}{cccccc}
\multicolumn{6}{c}{ Table 4. Sperm Viability (\%) } \\
\cline { 2 - 4 } Treatment & \multicolumn{3}{c}{ Repetition } & \multirow{2}{*}{ Total } & Average \\
\cline { 2 - 5 } & $\mathbf{1}$ & $\mathbf{2}$ & $\mathbf{3}$ & & \\
\hline A & 78 & 82 & 79 & 239 & 79.67 \\
B & 77 & 69 & 68 & 214 & 71.33 \\
C & 61 & 59 & 69 & 189 & 63.00 \\
\hline Total & & & & 642 & \\
\hline Control & 92 & 90 & 90 & 272 & 90.66 \\
\hline
\end{tabular}


The variance analysis (Table 5) explained that the F-ratio was higher than both the $5 \%$ and $1 \%$ F-Table. In other words, the treatment (pulse length during the electroporation) had significant influence towards the viability of Ornamental Japanese carp fish sperm. The polynomial test (Fig. 2) resulted in a linear equation, which was $Y$ $=-8.3333 x+88$ and the correlation coefficient between the pulse length and the sperm viability was $\mathbf{R}^{2}=1$ meaning there was strong correlation between pulse length treatment pasca electroporation and the viability of Ornamental Japanese carp fish sperm.

\begin{tabular}{lccccccc}
\multicolumn{7}{c}{ Table 5. Variance Analysis } \\
\hline $\begin{array}{l}\text { Source of } \\
\text { Variance }\end{array}$ & df & SS & MS & F & F 5\% & F 1\% \\
\hline Treatment & 2 & 416 & 208 & & & \\
Random & 6 & 113 & 18 & 11 & 5.14 & 10.92 \\
Total & 8 & & & & & \\
\hline
\end{tabular}

Based on the data analysis, the percentage of the sperm viability plummeted as the pulse length during the electroporation was getting longer. It was then concluded that pulse length duration may decrease the viability of Ornamental Japanese carp fish sperm, similar to their motility. Normally, sperm viability is between 1 and 2 minutes after stripping [16]. Changes in infrastructure of the plasma membrane, as well as the loss of some mitochondrial matrices and decreased electron density of the mitochondrial matrix may result in loss of spermtozoa viability [17]. Treatment A (0.5 ms) resulted in the highest percentage of post treatment viability. It was the lowest pulse length treatment.

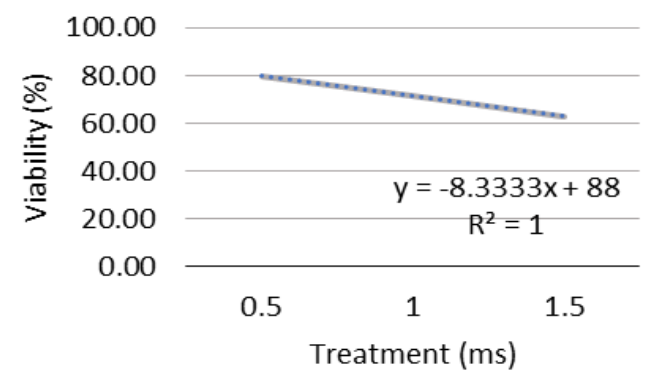

Figure 2. Correlation between Different pulse length and Sperm Viability Chart

Electroporation in sperm may stretch sperm cells as high-intensity electric fields temporarily destabilized cell membranes and during that period, membranes were highly permeable with exogenous molecules (DNA or RNA) located around the cell medium. DNA then moved into the cell (internalization process) through this permeable hole. When the electric field stopped (turn off), the inner membrane holes closed and the exogenous DNA entered the cell [17].

Therefore, the 30-volt electric level and pulse length applied during the treatment may be used as electroponic method where sperm became medium to produced transgenic Koi fish. Maintining motility and viability of sperm was important in conducting transgenesis technique where sperm became gene carrier vector.

\section{CONCLUSION}

Based on the result of the experiments that was giving different pulse length during electroporation towards the Ornamental Japanese carp (Cyprinus carpio Var. Koi) fish sperm, it was revealed that pulse length has significant influence toward motility and viability of fish sperm. 30 volt electric volatage level and 0.5 milisecond of pulse length results in the highest percentage of the motility and viability of Ornamental Japanese carp (Cyprinus carpio Var. Koi) fish sperm.

\section{REFERENCES}

[1] Alimuddin, G. Yhosizaki, O. Carman, K. Sumantadinata. 2003. Aplikasi transfer gen dalam akuakultur. Jurnal Akuakultur Indonesia. 2(1). 41-50.

[2] Lavitrano, M., M. Busnelli, M.G. Cerrito, R. Giovannoni, S. Manzini, A. Vargiolu. 2006. Sperm mediated gene transfer. Reprod. Fertil. Dev. 18(1-2). 19-23.

[3] Caelers, A., N. Maclean, G. Hwang, E. Epper, M. Reinecke. 2005. Expression of endogenous and exogenous growth hormone (GH) messenger (m) RNA in a GH-transgenic tilapia (Oreochromis niloticus). Transgenic Res. 14. 95-104.

[4] Tsai, H.J. 2000. Electroporated sperm mediation of a gene transfer system for Finfish and Shellfish. Mol. Reprod. Dev. 56. 281284.

[5] Symond, J.E., S.P. Walker, F.Y.T. Sin. 1994. Electroporation of salmon sperm with plasmid DNA; evidence of enchanned sperm/DNA assosition. Aquaculture. 199. 313-327.

[6] Gusrina. 2011. Introduksi dan ekspresi gen hormon pertumbuhan ikan Nila (Oreochromis niloticus) pada ikan Lele (Clarias sp.). PhD Thesis. Graduate School, Bogor Agricultural Univeristy. Bogor.

[7] Faqih, A. 2011. Penurunan motilitas dan daya fertilitas sperma ikan lele dumbo 
(Clarias spp.) pasca perlakuan stress kejutan listrik. J. Exp. Life Sci. 1(2). 56-110.

[8] Anitasari, S., A. Soeprijanto, A.R. Faqih. 2015. The effectiveness of hrGFP Gene Reporter role in Carp Fish (Cyprinus carpio) transgenesis process based on convocal microscopy analysis. J. Exp. Life Sci. 5(2). 82- 88.

[9] Buwono, I.D., Iskandar, M.U.K. Agung, U. Bubhan. 2016. Perakitan ikan lele (Clarias sp.) transgenic dengan teknik elektroporasi sperma. Jurnal Biologi. 20(1). 17-28.

[10] Susilowati, T. 2011. Spermatology. University of Brawijaya. UB Press. Malang.

[11] Dewi, R.R.S.P.S. 2010. Studi over-ekspresi gen penyandi hormon pertumbuhan melalui elektroforesis sperma untuk membuat Ikan Patin Siam transgenik cepat tumbuh. PhD Thesis. Graduate School, Bogor Agricultural Univeristy. Bogor.

[12] Tsong, T.Y. 1983. Voltage modulation of membrane permeability and energy utilization in cells. Biosci. Rep. 3. 487-505

[13] Hafez, E.S.E. 1987. Reproduction in farm animal, $5^{\text {th }}$ Ed. Lea and Febiger. Philadelphia.

[14] Sin, F.Y.T., S.P. Walker, J.E. Symonds, U.K. Mukherjee, J.G.I. Khoo, I.L. Sin, 2000. Electroporation of salmon sperm for gene transfer: efficiency, reliability, and fate of transgene. Mol. Reprod. Dev. 56. 285-288.

[15] Alimuddin, L.I. Purwanti, M.H.F. Ath-thar, C. Muluk, O. Carman, K. Sumantadinata. 2009. Aktivitas promoter â-aktin Ikan Medaka Jepang (Oryzias latipes) pada Ikan Mas (Cyprinus carpio). Jurnal Natur Indonesia. 11(2). 70-77.

[16] Effendi, M.I. 1997. Biologi Perikanan. Yayasan Nusatama. Bogor.

[17] Woynarovich, E., L. Horvarth. 1980. The Artificial Propagation of Warm-Water Fin Fish. A Manual for Extention. FAO Fis. Tech. 201. 